\title{
Kentlerin Aydınlatılması Bağlamında Işık Kirliliği Sorunsalı ve İzmir Büyükşehir ve İlçe Belediyelerinin Yaklaşımları*
}

\author{
The Problem of Light Pollution In The Context of Lighting Cities and The Approaches of Izmir \\ Metropolitan and District Municipalities
}

\section{Tülin DEMİRCI ${ }^{a}$}

${ }^{a}$ Doktora Öğrencisi, Dokuz Eylül Üniversitesi, İzmir, Türkiye, avcutulin.92@gmail.com, ORCID: 0000-0001-6463-7367

\begin{abstract}
ÖZ
İnsanların gece hareket kabiliyetini arttırmak, güvenlik endişelerini gidermek ve ilkel karanlık korkularını ortadan kaldırmak amacıyla kullandıkları aydınlatma araçlarının bilinçsiz bir șekilde kullanılması sonucu ortaya çıkan 1şık kirliliği insan hayatı ve ekosisteme ciddi zararlar vermektedir. Ulusal ve uluslararası literatür incelendiğinde 1şık kirliliğiyle bağlantılı çalışmaların sınırlı sayıda olduğu anlaşılmıştır. Bu bağlamda çalışmanın temel amacı 1şı kirliliğinin nedenleri ve tipleri üzerinde durarak literatürde eksikliği hissedilen bilimsel çalıșma açığını kapatmaktır. Ayrıca İzmir Büyükşehir Belediyesi ve İzmir ili sınırları içerisinde bulunan ilçe belediyelerinin 1şık kirliliği konusunda hangi plan ve projeleri gerçekleştirdiğinin tespit edilmesi çalışmanın diğer amacını oluşturmaktadır. Çalışmada nitel araştırma yöntemi olan doküman analizi yöntemi kullanılmıştır. Belediyelerin 1şık kirliliği konusundaki yapmış olduğu çalışmalar Cumhurbaşkanlığ İletişim Merkezi (CIMER) aracılığıyla alınmış olup verilerin analizinde içerik analizi yöntemi kullanılmıştır. Çalışmada Gaziemir, Karabağlar gibi nüfus açısından fazla olan belediyelerin 1şık kirliliği konusunda plan ve projelerinin olmadığ Kiraz, Urla, Bergama gibi belediyelerin de 1şık kirliliği konusunda sorumluluklarını net bir şekilde farkında olmadıkları sonucuna ulaşılmıştır.
\end{abstract}

Anahtar Kelimeler: Aydınlatma, Işsk Kirliliği, İlçe Belediyeleri, İzmir Büyükşehir Belediyesi.

\begin{abstract}
When the national and international literature is examined, it is understood that there are limited number of studies related to light pollution. In this context, the main purpose of the study is to close the scientific study gap, which is felt in the literature, by focusing on the causes and types of light pollution. In addition, the other purpose of the study is to determine which plans and projects have been carried out by the Izmir Metropolitan Municipality and the district municipalities within the borders of Izmir province on light pollution. The document analysis method, which is a qualitative research method, was used in the study. The studies carried out by the municipalities on light pollution were obtained through the Presidency Communication Center (CIMER), and the content analysis method was used in the analysis of the data. In the study, it was concluded that the municipalities such as Gaziemir and Karabağlar, which have a large population, do not have plans and projects on light pollution, and municipalities such as Kiraz, Urla, Bergama are not clearly aware of their responsibilities regarding light pollution.
\end{abstract}

Keywords: Lighting, Light Pollution, District Municipalities, Izmir Metropolitan Municipality,

\footnotetext{
* Bu makalede bilimsel araştırma ve yayın etiği ilkelerine uyulmuştur. / In this article, the principles of scientific research and publication ethics were followed.

Atıf-Reference: Demirci, T. (2021). Kentlerin Aydınlatılması Bağlamında Işık Kirliliği Sorunsalı ve İzmir Büyükşehir ve İlçe Belediyelerinin Yaklaşımları. Bitlis Eren Üniversitesi Sosyal Bilimler Dergisi, 10 (2), 72-80.
} 


\section{GÍRİŞ}

Sağlıklı kentleşme önündeki en önemli engellerden bir tanesi ekosistemin bozulmasıdır. İklim değişikliği, atıkların doğaya bilinçsizce bırakılması, fosil enerji yakıtlarının kullanılması gibi ekosistemin bozulmasına sebebiyet veren olumsuz durumlara son dönemde 1şık kirliliği de eklenmiştir. Işık kirliliği insan ihtiyaçlarının karşılanması amacıyla doğal ışıkların yetersiz kaldığı durumlarda insan eliyle oluşturulan yapay aydınlatmanın insan sağlığına ve ekosisteme zarar vermesi olarak tanımlanmaktadır. Işık kirliliği canlıların yaşam alanı olarak tanımlanan biyosferi etkileyen bir kirlilik olarak kabul edilmektedir.

Sanayi devrimi sonrası ortaya çıkan hızlı ve plansız kentleşme ve yapılaşma nedeniyle 1şık kirliliği artış göstermiştir. Ulusal ve uluslararası literatürden de anlaşıldığı üzere kamu kurumları ve bireyler çevre konusunda endişe duysalar bile 1şık kirliliği diğer çevresel konular gibi hak ettiği değeri görememektedir.

$\mathrm{Bu}$ bağlamda çalışmada 1şık kirliliği konusunda farkındalık oluşturarak İzmir ili örneğinde belediyelerin 1şık kirliliği konusunda ne tür çalışmalarının olduğunun tespiti amaçlanmıştır. Çalışmada nitel bir araştırma olan doküman analizi yöntemi kullanılmıştır. CİMER (Cumhurbaşkanlığı İletişim Merkezi) kanalı kullanılarak İzmir Büyükşehir Belediyesi ve 30 ilçe belediyesine 1şık kirliliği konusunda hangi plan, proje ve çalışmaları olduğu sorusu sorulmuştur. Alınan cevaplar içerik analizi yöntemiyle değerlendirilmiştir.

Çalışmada Gaziemir, Çeşme, Selçuk belediyelerin ışık kirliliği konusunda bir çalışması bulunmamakta Kiraz, Urla, Bergama, Seferihisar belediyelerinin mevzuattan kaynaklanan sorumlulukları konusunda bilgi sahibi olmadığ tespit edilmiştir. Belediye personellerinin bilgi eksikleri giderilerek 1şık kirliliğinin önlenmesi konusunda çevresel kirliliğe neden olmayacak çevre dostu aydınlatma sistemleri oluşturmaları kirliliğin kaynağında önlenmesi konusunda büyük önem taşımaktadır. Aydınlatma ve aydınlatma sistemleri hem kirliliği önlemede hem de güvenliği sağlamak açısından üzerinde durulması gereken bir konudur. Bu bağlamda izleyen bölümde aydınlatma ve aydınlatma türleri üzerinde durulacaktır.

\section{AYDINLATMA}

İnsanlar tarih öncesi devirlerden günümüze hayatlarını devam ettirebilmek için çeşitli malzeme ve kaynaklara ihtiyaç duymuşlardır. Bu ihtiyaç duyulan kaynaklar içerisinde aydınlatma önemli bir yer teşkil etmektedir. İnsanlar 19. yüzyıla gelinceye kadar aydınlatma gereksinimini mum, kandil, yağ lambaları gibi araçlarla gidermişlerdir (Özkaya, 2004). 16. yüzyılda özellikle Avrupa ülkelerinde meydana gelen hızlı nüfus artışı (Ultan, 2018: 83-84) ve 19. yüzyıl Sanayi devriminin yaratmış olduğu teknolojik gelişmelerin etkisiyle aydınlatma ihtiyacının karşılanması için farklı araç ve gereçler kullanılmaya başlanmıştır (Küçükalay, 1997).

Uluslararası ve ulusal literatürde aydınlatma kavramının net bir şekilde anlaşılması için 1şık kavramı üzerinde durulmalıdır. Günlük hayatımızda iş ve işlemlerin yürütülmesinde önemli bir rol oynayan 1şık; güneşten gelen enerji ve maddeleri görmeyi mümkün kılan erke olarak tanımlanmıştır (OXFORD, 2021). Bir diğer tanımda ise görmeyi mümkün kılan şey, insan gözüyle görülebilen bir erke olarak tanımlanmıştır (MW, 2021). Bununla birlikte fizik biliminde 1şık; kızılötesi, ultraviyole, X 1şınları, radyo dalgaları ve daha fazlası gibi görünmez formlar dâhil olmak üzere elektromanyetik ölçeğin tüm bölümleri olarak tanımlanmaktadır. (SPİE, 2015). Kuzey Amerika Aydınlatıcı Mühendislik Topluluğu tarafından yapılan tanımda ise, 1şık göz retinasını hareketlendiren ve görsel bir his yaratabilen enerji olarak tanımlanmıştır (LRC, 2000).

Aydınlatma kavramı ise ışık ile birlikte tanımlanan bir olgudur. Işık kavramı olmadan aydınlatmadan söz edilmesi mümkün değildir. Buna göre aydınlatma; nesnelerin ve çevrenin gereği gibi görülebilmesini sağlamak amacı ile belli alan veya alanlara 1şık uygulamak olarak tanımlanmıştır (Şirel, 1991). Bir diğer tanımda ise belli bir 1şık kaynağının bir nesne veya çevreye 1şık yollayarak o nesneyi gözle görünür hale getirmesi aydınlatma olarak tanımlanmıştır. Bu tanımda da aydınlatmanın nesneleri ışık vasıtasıyla görünür kıldığı üzerinde durulmuştur. İnsanların çevresini algılaması ve çevresinde ne olup bittiğini anlayabilmesi, işitme, dokunma, görme, koku alma vb. duyular aracılığı ile sağlanmaktadır. Çevreyi algılayarak değerlendirmede görsel duyunun payı \%95'tir. Bu görsel algının sağlanması için de 1şık uygulanmaktadır (Şirel, 2007). Akşam belli bir saatten sonra da bulunduğumuz mekândan yararlanabilmemiz için aydınlatmaya ihtiyaç duyarız. Aydınlatma çevremizdeki nesneleri seçebilmemizi, bulunduğumuz mekândan daha iyi yararlanabilmemizi, güvenliğimizi sağlaması açısından önemlidir. İyi bir aydınlatma kentsel alanlarda bireylerin görme yeteneğini arttırarak güvenlik duygusunu arttırmaktadır. Bu duruma ek psikolojik açıdan kendisini güvende hisseden birey bulunduğu ortamda daha mutlu hissetmektedir (Özkaya ve Tüfekçi, 2011).

\section{AYDINLATMA TÜRLERI}

Literatürde ilgi alanlarına göre aydınlatmanın çeşitli şekillerde tanımlandığı görülmektedir. Işığın kökenine göre yapılan tanımlar doğal-yapay olarak 2'ye, aydınlatılan yere göre yapılan tanımlar ise iç ve dış olarak 2'ye ayrılmaktadır.

\subsection{Işığın Kökenine Göre Aydınlatma}

\subsubsection{Doğal Aydınlatma}

Aydınlatmada güneş kaynağından yararlanılması doğal aydınlatmadır. Güneş ışığı birçok bakımdan canlı ve devingen bir özelliğe sahiptir. Bu ise insan doğasına uygun ve insanı olumlu etkileyen bir özelliktir. Geçmişten bugüne insan var olduğu günden bu yana, böyle bir 1şık içinde gelişip, bütün organizması buna göre oluşmuştur. Bu açıdan da doğal aydınlatma dediğimiz güneş 1şı̆̆ı insan psikolojisini olumlu etkileyen bir özelliğe sahiptir. Çatı aydınlatması, pencere aydınlatması ve doğada insan eli değmeden yararlanılan aydınlatma doğal aydınlatma örnekleri arasındadır. 


\subsubsection{Yapay Aydinlatma}

Teknolojik gelişmelerin artmasıyla birlikte bireylerin kapalı alanlarda geçirdikleri zamanın da arttı̆̆ı görülmektedir. Uzayan iş yükleri ve farklılaşan hayat şekilleri doğal aydınlatmanın insan ihtiyaçlarını karşılayamaması sonucunu doğurmuştur. Yine günümüzün teknolojik gelişmeleri ışığın kontrol edilebilir ve taşınabilir yapıya kavuşması yapay aydınlatmanın ortaya çıkmasını sağlamıştır. Doğal ışığın olmadığı veya yetersiz olduğu durumlarda kullanılan yapay aydınlatma; insan eliyle oluşturulan kontrollü aydınlatmayı ifade eden bir kavramdır (Turgay ve Altuncu, 2011: 171). Bina ve kapalı mekânlardaki aydınlatma araçları kullanılarak yapılan aydınlatma yapay aydınlatmanın en önemli örnekleri arasındadır.

\subsection{Aydınlatılan Yere Göre Aydınlatma}

\subsection{1. İ̧ Aydınlatma}

Çeşitli mimari yapılarla doğal aydınlatmanın gerçekleştiği çevreden ayrılan iç mekânların aydınlatılması iç aydınlatma olarak tanımlanmıştır. Haneler, hastaneler, sinema ve tiyatro salonları, fabrikalar bu aydınlatma türüyle aydınlatılmaktadır (MEB, 2011).

\subsubsection{Dış Aydınlatma}

Yapı dışı ölçeklerdeki aydınlatmaya verilen addır. En bilinen örneği sokak lambaları, yol ve cadde armatürleri ve projektörlerdir. Dış mekân aydınlatmasının ilk adımları 17. yüzyılda cadde ve sokakların güvenlik gerekçesiyle aydınlatılmasıyla başlamıştır. Türkiye'de ise dış mekân aydınlatması ilk kez 1914 yılında İstanbul ilinde yapılmıştır (Ankara Üniversitesi, 2020)

\section{AYDINLATMANIN NEGATIF ETKİSi: IŞIK KİRLILIĞ̈̇}

İnsan nüfusunun artması ve yerleşim alanlarının doğal yaşam alanlarına yaklaşması sonucunda aydınlatma ihtiyacı büyük oranda artmıştır. İklim değişikliği, çevresel kirlilik gibi insan kaynaklı faaliyetler nedeniyle gittikçe kırılgan hale gelen ekosistemler yapay aydınlatmanın olumsuz etkisi olan ışık kirliliğine maruz kalmaktadır. Literatürde konuyla ilgili çalışmalar sınırlı olsa da 1şık kirliliği çevre kirliliğinin en hızlı büyüyen ve yaygın etkilerini içerisinde barındıran kirlilik türlerinden birisidir (Chepesiuk, 2009).

Literatür incelendiğinde 1şık kirliliğiyle ilgili tanımların sınırlı olduğu tespit edilmiştir. Bilinen ilk sistematik tanım ise Uluslararası Gökyüzü Derneği tarafından yapılmışır. Bu tanımda ışık kirliliği; yapay ışı̆̆ın uygunsuz veya aşırı kullanımı sonucunda insan, hayvan ve bitkilerin olumsuz bir şekilde etkilenmesi olarak tanımlanmıştır. Aydınlatma araçlarının çevresel etkileri düşünülmeden bilinçsiz bir şekilde çevreye yerleştirilmesi durumunda 1şık kirliliğinin ortaya çıkma ihtimali oldukça yüksektir (IDA, 2021).

Bir diğer çalışmada ise 1şık kirliliği gökyüzü kaynaklı aydınlatmanın insan eliyle bozularak doğal ekosisteme verilen zarar olarak tanımlanmıştır. İnsan eliyle meydana gelen bu değişiklik gökyüzünü daha parlak hale getiren yapay ışıkların yeryüzüne çeşitli alanlara yerleştirilmesini ifade etmektedir. Bu uygulama biyosfere zarar veren bir kirlilik olarak kabul edilmektedir (Sharıff, Osman ve Faid, 2016: 1-2). Bir diğer tanımda ise insan yapımı aydınlatma araçlarının insan ihtiyacını karşılayabilecek seviyeden fazla kullanılması nedeniyle doğal döngünün bozularak ortaya çıkan çevresel kirlilik, 1şık kirliliği olarak tanımlanmaktadır. Işık kirliliği sadece şehirleri değil tüm dünyayı etkileyen bir nitelik taşımaktadır. Astronomiden, ekolojiye kadar birçok alanda doğa ve yaşam kalitesini düşürüp canlı hayatına ciddi zararlar vermektedir (Gaston, 2013).

Teorik alanda yapılan çalışmalar uygulamaya da yansımış olup 2016 yılında hazırlanan Dünya Yapay Gece Gökyüzü Parlaklığı Atlasında dünya nüfusunun \%80'inin doğal olmayan yapay aydınlatmaya maruz kaldığı ifade edilmiştir (IDA, 2016).

Işık kirliliğinin temel olarak 5 türü vardır (Rajkhowa, 2012: 862-863);

Hafif Aydınlatma Sonucu Oluşan Kirlilik: Aydınlatılma hedefi olmayan yerlere düşen 1şıkların oluşturduğu kirliliğe verilen addır. Sokak aydınlatmalarından evlerin içerisine giren düşük kelvin dereceli ışık bu konuda verilecek en temel örnek arasında yer almaktadır.

Aşırı Aydınlatmadan Kaynaklanan Kirlilik: Iş̧ı̆ın aşırı ve gereksiz kullanılmasından kaynaklanan kirliliktir. Özellikle metropollerde ve büyükşehirlerde karşımıza çıkmaktadır.

Göz Kamaştırıcı Işsklardan Kaynaklanan Kirlilik: Görselliği arttırmak amacıyla kullanılan parlaklığı yüksek 1şıkların oluşturduğu kirliliktir. Bu kirlilik ışığın hassas canlılara zarar vermesine ek olarak sürücü ve yayaların görüş açılarını daralttığı için trafik güvenliğine zarar vermektedir.

Işık Dağınıklığından Oluşan Kirlilik: Özellikle sokak 1şıkların ve reklam panoları gibi görsel ögelerin yoğun olduğu yerlerde ortaya çıkan kirlilik türüdür. Pilotların pist ışıklarının banliyö ışıklarını karıştırması ihtimalinin yüksek olmasından dolayı ışık dağınıklığı en çok havacılık sektörünü etkilemektedir. kirliliktir

Gökyüzü kirliliği: Yoğun aydınlatma nedeniyle yerleşim bölgeleri üzerindeki gökyüzünün parlamasından kaynaklanan 


\section{IŞIK KİRLILİĞİNIN OLUMSUZ ETKİLERİ}

Işık kirliliğinin çevre ve insan sağlı̆̆ı üzerindeki olumsuz etkileri oldukça fazladır. Bu başlık altında bu etkiler üzerinde durulacaktır.

\section{1. İnsan Sağlığı Üzerindeki Etkileri}

İnsanlar doğası gereği sabit bir gece-gündüz döngüsüne ihtiyaç duymaktadırlar. Yapay ışığa çok fazla maruz kalmak melatoninin yapısını bozarak uyku bozuklukları, kötü iş performansı, dikkat dağınıklığı, kilo artışı, stres ve kanser hastalıklarına sebep olabilir (Smolensky, 2013: 1203-1204). Nitekim vücuttaki melatonin dengesizliğinin meme kanseri riskini önemli düzeyde arttırdığına yönelik önemli sayıda çalışma bulunmaktadır (Topal, Öter ve Korkmaz, 2009: 142; Çimen, Akbaş ve Erbaş, 2018: 40). Yine aşırı 1şıklı ortamlarda çalışmanın ve konser, sinema gibi ortamlarda gözün yorucu 1şıklara belli aralıklarla maruz kalması göz sağlığını olumsuz etkilemektedir (Bostanc1, 2016: 97).

Işıklandırmanın insan psikolojisi üzerinde de çeşitli etkileri olduğunu ortaya koyan çalışmalar bulunmaktadır. Işıklandırmanın insan sağlığına olan etkileri analiz edilmeden aydınlatma araçlarının kullanılması hallerinde bireylerin psikolojisini ve biyolojik sistem hormonlarını olumsuz etkileyerek kişinin kendisini psikolojik olarak sağlıksız hissetmesine neden olabilmektedir (Rea, 2002: 15).

\subsection{Ekolojik Denge Üzerine Etkileri}

Işık kirliliği insanlar üzerinde olduğu kadar ekolojik sistem üzerinde de çeşitli tahribatlar yaratmaktadır. Aşırı 1şıklandırma kaplumbağa, kuş, kurbağa, semender gibi canlıların görsel algılarını bozarak gezinme ve avlanma yeteneklerine zarar vermektedir. Yoğun 1şık kirliliğine maruz kalan hayvanlarda ayrıca gece ve gündüz algısı bozularak zihinsel sorunlar ortaya çıkmaktadır. Özellikle yıldızların ve ayın ışığından yararlanarak geceleri göç eden kuşların çoğu yapay ışıklar nedeniyle yollarını kaybetmektedir (Meyer, T.B).

Yarasa gibi geceleri avlanan memeli hayvanlar da yapay 1şıklar nedeniyle görme ve hissetme yeteneklerini kaybederek avlanma gibi temel zorunluluklarını yerine getirememektedir. Yine özellikle geceleri yarasalar ormansız alanlara tohum taşıyarak ekosistemin devamını sağlamaktadır. Bu aşırı aydınlatma nedeniyle dağıtım hızı oldukça düşen yarasaların dağıtım yapamaması nedeniyle ekosistem ciddi zararlar görmektedir (Bennie, Davies, Cruse, Inger ve Gaston, 2015: 1-5).

Okyanus içerisinde yaşayan deniz kaplumbağalarının yavruları yumurtadan gece vakitlerinde çıkmaktadır. Yavrular okyanus yüzeyine yansıyan parlak yapay 1şıklar nedeniyle dışarı çıkmamakta bu yüzden her yıl milyonlarca yavrunun öldüğ̈̈ görülmektedir (IDA, 2020).

Ekosistem üzerindeki olumsuz etkilerine yönelik örnekler arttırılabilmekle birlikte Birleşmiş Milletler tarafindan 22.02.2020 tarihinde Göçmen Yabani Hayvan Türlerinin Korunmasına İlişkin Taraflar Konferansının 13'cüsü gerçekleştirilmiştir. Bu toplantıda stratejik ortaklar tarafından başta göçmen kuşlar, deniz kaplumbağaları ve yarasalar olmak üzere etkilenen diğer hayvanların ışık kirliliğinden kaynaklanan sorunlarının çözülmesi gerekliliği vurgulanmıştır. Ayrıca bu zirveden sonra toplanacak ilk zirve için 1şık kirliliğinden kaynaklanan sorunların çözülmesi amacıyla taraf devletlerden rapor hazırlanması istenmektedir. Dünya Göçmen Kuşlar Günü'nün nasıl kutlanabileceğine ilişkin öneriler de COP 13 (2007 Birleşmiş Milletler İklim Değişikliği Konferansı) toplantısında üzerinde durulması gereken konu başlıkları arasında yer almaktadır (UN, 2020).

\subsection{Bilimsel Hayata Etkileri}

Işık kirliliği bilimsel ilerlemeler önünde de çeşitli engeller oluşturmaktadır. Karanlık bir gökyüzü evren üzerinde çalışma yapmanın ön koşuludur. Gökbilimciler uzayda yer alan nesnelerden gelmekte olan zayıf 1şık sinyallerini karanlık bir gökyüzü olmadan alamazlar. Bu açıdan birçok astronomik gözlemevi, şehirlerin ve kasabaların ışı̆̆ından kaçmak için uzak yerlere inşa edilmektedir. Buna rağmen birçok gözlemevleri de 1şık kirliliği tehdidi ile karşı karşıyadır (NAOJ, 2016).

\section{KENTSEL AYDINLATMA KONUSUNDAKİ HUKUKİ DÜZENLEMELER}

Günümüzde kentsel dış mekânların aydınlatılması başta güvenlik ve kültürel faaliyetler olmak üzere özel bir önem teşkil etmektedir. 03.07.2005 tarihinde yürürlüğe giren 5393 sayılı Belediye Kanunu’nda belediyelerin görev ve yetkileri detaylı olarak hüküm altına alınmıştır. Buna göre büyükşehir, il belediyeleri ve nüfusu 10.000'i geçen belediyelerin belediye meclisi kararıyla faiz almadan 10 yıllık sürelerle aydınlatma çalışmalarını yapabileceği veya yaptırabileceği hüküm altına alınmıştır. Yine kanunun 67. maddesinde bu yapılan aydınlatma araçlarının bakımı konusundaki yetkilendirmenin belediye meclisi kararıyla belirleneceği hükme bağlanmıştır. 73. maddenin birinci ek fikrasında ise belediye meclisi kararıyla uygun görülen binaların cephelerinde özel aydınlatma ile çevre düzenlemesi yapılacağı ifade edilmektedir (TBMM, 2005). 5393 sayılı kanunun kentsel alanların aydınlatılması konusunda belediyeleri yetkili kıldığ 1 görülmektedir.

Kentsel aydınlatma konusunda üzerinde durulması gereken diğer hukuki düzenleme ise 27.07.2013 tarihinde 28720 sayılı Resmi Gazetede yayımlanarak yürürlüğe giren Genel Aydınlatma Yönetmeliğidir. Yönetmeliğin temel amacı genel aydınlatma konusundaki görev ve sorumlulukların tespit edilerek enerji verimliliğini sağlamaktır. Yönetmelik aydınlatma tüketimlerinin ölçülüp aydınlatma komisyonunun oluşturulması ve aydınlatma konusundaki teknik esaslar konusundaki usul ve esasları kapsamaktadır. Yönetmelikte genel aydınlatmanın tanımına da yer verilmiştir. Buna göre yönetmeliğin 4 . maddesinde tanımlanan genel aydınlatma; 
Otoyollar ve özelleştirilmiş erişme kontrollü karayolları hariç, kamunun genel kullanımına yönelik bulvar, cadde, sokak, çıkmaz sokak, yürüyüş yolu, alt-üst geçit, yaya alt-üst geçidi, köprü, meydan ve yaya geçidi gibi yerler ve mevcut genel aydınlatma tesisi güzergâhında yer alan yerlerin kullanılmasına hizmet eden ve bunların devamı niteliğindeki yerler ile halkın ücretsiz kullanımına açık ve kamuya ait park, bahçe, tarihî ve ören yerlerinin aydınlatılması ile trafik sinyalizasyonununu kapsamaktadır.

5393 sayılı kanunda verilen görevlerle uyumlu olarak yönetmelikte oluşturulan aydınlatma komisyonunda ilgili belediyenin de temsilcilerinin bulunacağı hüküm altına alınmıştır. Yönetmeliğin 9. maddesinde komisyonda yer alacak üyeler detaylı bir şekilde hüküm altına alınmıştır. Buna göre ilgili ilin valisi veya bu vali tarafından yetkilendirilecek vali yardımcısı başkanlığında, il büyükşehir statüsünde ise; büyükşehir belediyelerinden iki üye, elektrik dağıtım şirketlerinden ve konuyla doğrudan ilgili belediyelerden birer üye ve TEDAŞ temsilcilerinin katılımcılarından oluşmaktadır. Büyükşsehir statüsünde olmayan illerde ise vali veya görevlendireceği vali yardımcısı başkanlığında konuyla ilgili belediyelerden, il özel idaresinden ve dağıtım firmalarından birer üye ve TEDAŞ temsilcisinden oluşmaktadır.

Komisyon kamuya açık park, bahçe, sokak, tarihi alanlar gibi halkın kullanımı açık alanlara yapılacak aydınlatmaları, genel aydınlatma tesislerin kurulacağı yerleri, aydınlatma ile ilgili yatırım kararlarını, kamusal alanların aydınlatma şekillerini belirlemekle görevlidir. Kamu güvenliği dâhilinde dağıtım şirketlerinden elektrik kesintisi yapılmasını da talep etme yetkisine sahiptir. Komisyon Enerji ve Tabii Kaynaklar Bakanlığına karşı sorumludur

\section{IZMMIR BÜYÜKŞEHİR BELEDIYYSİ VE ILLÇE BELEDIYELERINIIN IŞIK KİRLIILİĞINE YÖNELIK ÇALIŞMALARI}

İzmir 11906.85 km2 yüzölçümüne sahip bir ildir. Aliağa, Balçova, Bayındır, Bayraklı, Bergama, Beydağ, Bornova, Buca, Çeşme, Çiğli, Dikili, Foça, Gaziemir, Güzelbahçe, Karabağlar, Karaburun, Karşıyaka, Kemalpaşa, Kınık, Kiraz, Konak, Menderes, Menemen, Narlıdere, Ödemiş, Seferihisar, Selçuk, Tire, Torbalı ve Urla olmak üzere toplam da 30 ilçeye sahiptir (İzmir Büyükşehir Belediyesi, 2021).

27.07.2013 tarihinde Resmi Gazete'de yayımlanan Genel Aydınlatma Yönetmeliği’nin amaç ve kapsamından hareketle aydınlatma komisyonu içerisinde değerlendirilen belediyelerin yönetmeliğin 6 . Maddesinde de belirtilen 1şık kirliliğine yönelik olarak yapmış oldukları ya da yapmayı planladıkları proje ve çalışmalar çalışmanın temel konusunu oluşturmaktadır. Bu anlamda İzmir Büyükşehir Belediyesi ve bağlı belediyelere bir sorumluluk düşmektedir. Işık kirliliği hem çevreye hem insanlığa vermiş olduğu zararla gündemi son dönemde oldukça meşgul eden bir konudur. Bu kirlilik sadece bir sağlik konusu olmamakla birlikte trafik, çevre, hayvanlar gibi birçok argümanı etkileyen de bir konudur. Bu bağlamda çalışmada İzmir Büyükşehir Belediyesi ve bağlı belediyelerin ışık kirliliği konusuna bakış açıları, bu konuda var ise yapmış oldukları çalışmalar yok ise yapacakları bir çalışma olup olmadığı araştırılmak istenmiştir.

Bu anlamda da CIMMER (Cumhurbaşkanlığı İletişim Merkezi) üzerinden ilk olarak 22.11.2019 tarihinde ve \#1902733737 başvuru numarası ile İzmir Büyükşehir Belediyesi ve bağlı belediyelere ulaşılarak bu yönetmelik kapsamında 1şık kirliliğine yönelik çalışmaları olup olmadığı konusunda bilgi alınmak istenmiştir. Bu doğrultuda "Enerji ve Tabii Kaynaklar Bakanlığı Tarafından Çıkartılan Genel Aydınlatma Yönetmeliği içerisinde sokak, cadde ve park gibi kamusal alanlarda 1şık kirliliğinin önlenmesine ilişkin hüküm bulunmaktadır. İzmir Büyükşehir Belediyesi ve ona bağlı ilçe belediyelerinin bu kapsamda yapmış olduğu çalışmalar var mıdır? Var ise proje ayrıntılarını paylaşabilir misiniz?" sorusuna 30 ilçe belediyesinden alınan cevaplar şu şekildedir;

Torbalı İlçe Belediyesi Fen İşleri Müdürlüğü, Gaziemir İlçe Belediye Başkanlığı Fen İşleri Müdürlüğü, Narlıdere İlçe Belediye Başkanlığı Fen İşleri Müdürlüğü, Menderes İlçe Belediye Başkanlığı Fen İşleri Müdürlüğü, Menemen İlçe Belediye Başkanlığı Fen İşleri Müdürlügüu, Çeşme İlçe Belediye Başkanlığı Park ve Bahçeler Müdürlüğü, Beydağ İlçe Belediye Başkanlığı, Selçuk İlçe Belediye Başkanlığı, Güzelbahçe İlçe Belediye Başkanlığı, Bergama İlçe Belediye Başkanlığı İmar ve Şehircilik Müdürlüğü, Foça İlçe Belediye Başkanlığı Fen İşleri Müdürlüğü, Kemalpaşa İlçe Belediye Başkanlığı, Karabağlar İlçe Belediye Başkanlığı Çevre Koruma ve Kontrol Müdürlüğü, Balçova İlçe Belediye Başkanlığı Fen İşleri Müdürlüğü tarafından sokak cadde ve park gibi kamusal alanlarda 1şık kirliliğinin önlenmesine ilişkin herhangi bir çalışma yapılmadığı belirtilmiştir.

Bayraklı Belediye Başkanlığı Park ve Bahçeler Müdürlüğü genel olarak genel aydınlatma yönetmeliğine uyulduğunu söylemiş ve ayrıntılı bir bilgi vermemiştir.

Çiğli Belediye Başkanlığı Fen İşleri Müdürlüğü; belediye bünyesinde bulunan park, bahçe ve yürüyüş yollarının kısım kısım genel aydınlatma kapsamına alındığı ancak geniş kapsamda bir projesinin olmadığını belirtmiştir.

Kiraz Belediye Başkanlığı Fen İşleri Müdürlüğü: vermiş olduğu cevapta Kiraz belediyesinin sorumluluğunda bulunan park ve bahçelerde ışık kirliliği bulunmadığını ifade etmiştir. "İlçemiz bütün mahallelerindeki Cadde ve sokakların aydınlatılması Gediz Elektrik Dağıtım Anonim Şirketi'nin sorumluluğunda olup konuyla ilgili gerekli bilgiyi bu kurumdan alabilirsiniz” diyerek Dağıtım şirketine yönlendirmiştir.

Urla Belediye Başkanlığı Fen İşleri Müdürlüğ̈̈; genel aydınlatma kapsamındaki alanların Gediz Elektrik Dağıtım Anonim Şirketi’nin sorumluluğunda bulunduğu için bu konuda hiçbir çalışma yapılmadığını belirtmiştir. 
Bergama Belediye Başkanlığı Fen İşleri Müdürlüğü; ise ilçedeki cadde ve sokak aydınlatmaları ile ilgili olan kurumun Gediz Elektrik A.Ş tarafından projelendirilerek yapıldığını belirtmiş ve belediyenin sorumluluğunda olan parklarda ise daha az 1şıklı (ki bu tanımlanmamıştır) ve yarı gece aydınlatması yapıldığı belirtilmiştir.

Seferihisar Belediye Başkanlığı Fen İşleri Müdürlü̆̆̈̈ de sokak aydınlatmalarıyla ilgili olarak Gediz Elektrik Dağıtım Anonim Şirketi'ne başvurulması gerektiğini belirtmiştir.

Görüldüğü gibi Kiraz, Urla, Bergama, Seferihisar belediyeleri 1şık kirliliğine yönelik sorumluluk hakkında yetki ve görev alanına girmemekte olduğunu belirterek çalışmanın dağıtım şirketi olan TEDAŞ ile yapılması gerektiğini söylemiştir.

Belediyelerin bir çalışma ya da projesi olmaması 1şık kirliliği konusunun yeni bir konu olması ve hukuki düzenlemelerinin gelişme aşamasında olmasından kaynaklı olduğu düşünülmektedir.

Alınan cevaplardan da görüldüğü üzere İzmir ilinde yer alan 30 ilçeden 17'inin 1şık kirliliği konusunda hiçbir çalışması bulunmamaktadır.

İzmir ili ilçe belediyeleri içerisinde 1şık kirliliği konusunda yönetmeliğe uygun olarak çeşitli çalışmalar gerçekleştiren belediyeler de bulunmaktadir.

\section{Buca Belediye Başkanlığı Tesisler Müdürlüğünden;}

"Belediyemiz sorumluluk bölgesinde ışık kirliliğinin önlenmesine yönelik genel aydınlatma tesislerinde TEDAŞ Tip Onay Belgesine sahip IEC, TSE gibi milli ve uluslararast standartlara uygun, LED armatüre sahip, gerekli Lux ve Lümen değeri hesaplanarak ürün seçimi yapılmaktadır. ” yanıtı alınmıştır.

Aliağa İlçe Belediye Başkanlığı sınırları içerisinde yer alan alanların tümünde proje düzeyinde gerekli çalışmaların titizlikle yürütüldüğü ve en kısa zamanda faaliyete geçirmek adına alt yapı çalışmalarının devam ettiği belirtilmiştir. Bu doğrultuda Aliağa Belediyesi Fen İşleri Müdürlüğünden;

"Belediyemiz bünyesinde projesi 2016 yılı uygulaması ise 2017 yılında başlatılan Genel Aydınlatma Yönetmeliği içerisinde sokak, cadde ve park gibi kamusal alanlarda gerek enerji sarfiyatı gerekse ışık kirliğini azaltmak adına bazı sokak ve caddelerde aydınlatma çalışması yapmış bulunmaktayız. Bu çalışmalar çerçevesinde mevcut bulunan sodyum buharlı ve metal halide tipinde olan aydınlatma armatürlerini, yeni nesil led aydınlatma armatürleri ile değiştirmiş bulunmaktayız. Mevcut aydınlatma armatürleri yapısı gereği ışık yolu dağınık olup, gerçek anlamda aydınlatması gereken alanın dışında gereksiz ve etrafi rahatsız edici seviyede çalışmaktadır. Ancak led armatürler amacına uygun yani gerekli olan alanı aydınlatma ile birlikte üzerinde bulunan özel lensler ile ışığl dă̆ıtmayarak ışık kirliliği de yapmamaktadır. Ayrıca enerji tüketimi açısından da yaklaşık \%30 oranında avantaj sağlamaktadır. Bu uygulamayı ilçemizin tamamına uygulamak adına proje ve maddi anlamda gerekli çallşmalar titizlikle yürütülüyor olup, en kısa zamanda faaliyete geçirmek adına alt yapı çalışmalarımız devam etmektedir. " yanıtı alınmıştır.

Bayındır Belediye Başkanlığı Etüt Proje Müdürlüğü; Genel Aydınlatma Yönetmeliği’nin 6. maddesinin 2. bendi (Genel aydınlatma kapsamındaki halkın ücretsiz kullanımına açık ve kamuya ait park, bahçe, tarihi ve ören yerleri ile yürüyüş yolu gibi yerlerdeki mevcut aydınlatma tesisleri ve yeni yapılacak tesislerde, aydınlatma düzeyleri en geç saat 02:00'den sonra yüzde elli oranında düşürülür) ve 6. Maddenin 3. Bendi (Bu madde kapsamında yapılacak aydınlatmalarda 1şık kirliliğine yol açılmaması ve azami enerji tasarrufu sağlanması için bu tesislerin işletilmesinden sorumlu ilgili kuruluşlar tarafindan gerekli önlemler alınır) hükümlerine atıfta bulunarak genel aydınlatma tesislerinde TEDAŞ Tip Onay Belgesine sahip, IEC, TSE gibi milli ve uluslararası standartlara uygun, LED armatüre sahip, gerekli lux ve lümen değeri hesaplanarak ürün seçimi ve tesis tasarımı yapılmakta olduğunu belirtmiştir. Bu bağlamda Bayındır Belediyesi'nin 1şık kirliliğine yönelik projeler gerçekleştirdiği ve çalışmalarını titizlikle yürüttüğünü söyleyebiliriz.

Tire İlçe Belediye Başkanlığından ise;

"Cadde ve sokakların aydınlatılmasının belediyemiz sorumluluğunda olmamakla birlikte yeni yapılan parklarımızda ışık kirliliğini önlemek için glop tipi armatürlerin kullanılmasından kaçınılarak bunların yerine üstü ve yanları muhafazalı yatay ve düşey aydınlık düzeylerini yaratan uygun tasarımlı direkt tipi armatürler kullanılmaktadır. Enerji tasarrufu amaçlı led armatürler veya yüksek basınçlı sodyum lambalar tercih edilmektedir. Aydınlatma miktarlarının fazla olmaması için lüx ve lümen değerlerine dikkat edilmektedir. " şeklinde cevap alınmıştır.

Aliağa, Bayındır ve Tire ilçe belediyesinden alınan cevaptan da anlaşıldığı üzere aydınlatmada kullanılan armatürlerin de 1şık kirliliğinin önlenmesinde önemli bir yeri bulunmaktadır. Belirtmek gerekir ki cadde ve sokak aydınlatmaları belediyelerin de sorumluluğu altında bulunan alanlardır. “Bu alanların yetki alanımızda bulunmamaktadır” ifadesi 5939 sayılı kanundan da anlaşılacağı üzere hukuki açıdan yanlış bir önermedir. Bu tip kanılar yetki karmaşasına yol açabileceği gibi aynı zamanda bu alanların 1şık kirliliği açısından önemsenmemesi sonucunu doğurma ihtimali bulunmaktadır. 
Konak Belediye Başkanlığı Fen İşleri Müdürlüğü; 2013 yılından bugüne kadar ışık kirliliği ve çevresel boyuttaki etkilerini azaltmak adına SL Tipinde (sokak armatürü 50-60 W) 283 adet, $160 \mathrm{~W}$ sokak armatürü 5 adet, 90 W sokak armatürü 76 adet ve 70 W sokak armatürü 58 adet olmak üzere toplamda 422 adet armatür ve 100'ün üzerinde parkta da yenileme çalışması gerçekleştirildiğini belirtmiştir.

Karşıyaka İlçe Belediyesi Fen İşleri Müdürlüğü; kendi sorumluluğunda olan parklarda öncelikle çok fazla enerji tüketen, çevre ve insan sağlığını olumsuz yönde etkileyen 125 Watt civa buharlı armatürlerin kullanımı sonlandırılarak daha az enerji tüketen 70 Watt sodyum buharlı armatür kullanımına geçiş yapmıştır. İlçe genelinde daha az enerji tüketen ve daha sağlıklı aydınlatma armatürleri kullanılmaktadır. Aydınlatma kontrollerinde Fotosel röle ve dijital zaman saatleri kullanılması ile gün batımı ve gün doğumlarında gecikmesiz ya da gereksiz yere aydınlatmaların çalışması önlenmiştir. Ayrıca led armatürlerin kullanıma geçilmesi programları dahilinde olup bu konudaki çalışmaları devam etmektedir.

Bornova Belediyesi Park ve Bahçeler Müdürlüğünden;

"Belediyemiz maddi kaynaklarının sınırlı olması sebebi ile 'Genel Aydınlatma Yönetmeliği' kapsamında büyük çapta ve toplu bir proje yapılamamıştır, ancak Belediyemizin maddi imkanları dahilinde Park ve Bahçeler Müdürlügü̈nün sorumluluğundaki alanlarda, 'Genel Aydinlatma Yönetmeliği'ne uygun ve tasarruf sağlayan zaman/tarih ve ışı şiddeti ayarlanabilen yeni LED teknolojili akıllı aydınlatma ürünleri temin edilmekte olup, parklarımızda kademeli olarak kullanılmaya başlanmıştır. ” şeklinde cevap alınmıştır.

Buradan da anlaşıldığı gibi Bornova Belediyesi de 1şık kirliğini önlemek adına LED teknolojisine önem vermiş ve kademeli şekilde kullanımını arttırmaya başlamıştır. Ancak bu tip çevresel projelerin hayata geçirilmesi için belediyelerin ekonomik yönden güçlü olması gerekmektedir (Ercan, 2018; Yontar ve Özer, 2018).

Ödemiş Belediye Başkanlığı; ilçede bulunan park aydınlatmalarında, kullanım yeri ve amacına uygun olacak biçimde projektör, LED veya tasarruf ampullü armatür seçimlerine dikkat edildiğini belirtmiştir.

İzmir Büyükşehir Belediye Başkanlığı Kentsel Tasarım ve Kent Estetiği Şube Müdürlüğü’nden ise

“Müdürlüğümüz kapsamında çalışılan klyı düzenleme projelerinde, uygun aydınlatma değerlerinin belirlenmesi, göz konforunun sağlanmasına yönelik kriterlere dikkat edilmektedir. " cevab1 alınmıştır.

Tüm bunlardan Dikili, Kınık Karaburun belediyelerinden bilgi alınamadığı için değerlendirmeye tabi tutulamamıştır.

Değerlendirilmeye alınan belediyeler incelendiğinde belediyeler arasında farklı yaklaşımlar olduğu görülmüştür. İlgili belediyeler bunun sorumluluğu altında olduğunu kabul ederek çalışma yapmaya yönelirken bazı belediyeler sorumluluk kabul etmemektedir. Bu durum yönetmelikte açıkça aydınlatma komisyonu içerisinde değerlendirilmiştir. Nitekim caddeler, parklar ve bahçeler belediyenin sorumluluğunda olan alanlardır. Bu sorumluluk alanlarının dağıtım şirketlerine yönlendirilmesi belediyelerin yetki ve görev alanları konusundaki bilgi eksikliğini göstermektedir.

2019 yılında CİMER üzerinden iletmiş olduğumuz bu soru 17.01.2021 tarihinde \#2100290111 başvuru numarası ile tekrar iletilmiştir. Bu ikinci başvuru yalnızca İzmir Büyükşehir Belediye Başkanlığı Kentsel Tasarım ve Kent Estetiği Şube Müdürlüğü tarafından 10.03.2021 tarihinde cevaplanmış olup şu ifadelere yer verilmiştir:

“Söz konusu başvuruda belirtilen konuda Müdürlügümüzce yürütülen bir çalışma bulunmamaktadır. Ancak yetki ve sorumluluk alanımıza dayanak olan İzmir İlan Reklam ve Tanıtım Yönetmeliğinde adı geçen konu hassasiyeti ile ilgili olarak aşağıda iletilen hükümler yer almaktadır: 'Konut alanlarl

Madde 14- Zemin ve giriş katlarda yer alan tanıtım panoları kendisi doğrudan ışık kaynă̆ı olmayacak ve çevreyi rahatsız etmeyecek şekilde ışıklandırlabilir.

\section{Kentsel çalışma alanları}

Madde 15- (1) b) Binaların zemin üstü katlarındaki tanıtım uygulamalarına dair esaslar aşağıdaki şekildedir: Binada konut kullanımı bulunmadı̆̆ durumlarda tanıtım unsurları kendisi doğrudan ışık kaynă̆ olmayacak biçimde ve çevreyi rahatsız etmeyecek şekilde ışıklandırılabilir. ",

Burada da farklı bir yönetmelik kapsamında değerlendirme yapılmış ancak belirtmiş olduğumuz yönetmelik kapsamında çalışma olmadığı belirtilmiştir. Son olarak da İzmir Büyükşehir Belediye Başkanlığı İklim Değişikliği ve Temiz Enerji Şube Müdürlüğü sorumuzu 20.02.2021 tarihinde cevaplamış ve söz konusu başvurumuz hakkında yürütülen herhangi bir çalışma ve proje bulunmadığını belirtmişlerdir.

Buradan hareketle söylenebilir ki birçok belediyenin 1şık kirliliğine yönelik çalışması bulunmamaktadır. Bazı belediyeler ise yönetmelikte açıkça belirtildiği halde bu konunun belediyenin sorumluluğunda olmadığını belirtmişlerdir. Yine bazı belediyeler ise 1şık kirliliği konusunun ne olduğunu bilmemekte ve farklı bir şekilde konuyu yorumlayabilmektedir. Ancak bakıldığında birçok belediyenin de bu konuda dikkatli ve özenli davrandığını söyleyebiliriz. 


\section{SONUÇ}

Teknolojinin de gelişmesiyle birlikte artan çevre sorunlarından bir tanesi olarak kabul edilen 1şık kirliliği; insan sağlı̆̆ ve ekolojik düzene vermiş olduğu zararlar nedeniyle üzerinde durulması gereken konuların başında gelmektedir. Kamu sağlığını olumsuz etkilemesi ve enerji verimsizliği yaratması nedeniyle konuyla ilgili kamu kurum ve kuruluşlarının işbirliği içerisinde plan ve projeler gerçekleştirmesi gereken bir alan olarak karşımıza çıkmaktadır.

Bu bağlamda 5393 sayılı kanunda ve Genel Aydınlatma Yönetmeliği'nde belediyelere kamusal alanların aydınlatılması sorumluluğu verilmiştir. Belediyeler bu sorumlulukla bağlantılı olarak enerji verimliliğini sağlayacak önlemler alması çevresel kirliliği azaltarak ekosistemin korunmasını sağlayacaktır.

Çalışmada ulusal mevzuat hükümleri 1şığında 1şık kirliliğinin olumsuz etkilerinden hareketle İzmir ili sınırları içerisinde yer alan belediyelerin plan ve projeleri üzerinde durulmuştur. CİMER kanalı kullanılarak İzmir Büyükşehir Belediyesi ve bağlı belediyelerine iletilen sorulara verilen cevaplarda Gaziemir, Çeşme, Selçuk gibi nüfus açısından yoğun belediyenin 1şık kirliliğine yönelik hiçbir çalışmasının olmadığını görmekteyiz. İnsan hayatından çevreye kısacası birçok alana olumsuz bir etkisi olabilen bu kavramın belediyeler tarafindan dikkatle incelenmesi ve uygun plan ve projelerin gerçekleştirilmesi gerekmektedir. Bu bağlamda bazı ilçe belediyelerinin bu konuda bir çalışması olmaması ve hatta bazı belediyelerden konunun yetkisi dâhilinde bile olmadığı cevabı alınması bu konuya önem verilmediğini göstermektedir. Nitekim 5393 sayılı belediye kanununda belediyelerin yetki alanları ayrıntısıyla tanımlanmıştır. Buna göre belediyelerin sorumluluğu açıktır. Yine de birçok belediye bu konuda bir çalışma yapmamış olsa da bazı belediyelerin titizlikle bu konuya dikkat etmesi ve 1şık kirliliğine sebep olabilecek armatürleri bile kullanmaması 1şık kirliliği olgusunun önemsenmediğini göstermektedir.

Belediyeler 1şık kirliliğinin önlenmesi konusunda çevresel kirliliğine neden olmayacak çevre dostu aydınlatma sistemleri oluşturmalıdır. Işık kirliliği konusundaki mevzuatın geliştirilmesi ve uygulanabilirliğinin arttırılması amacıyla başta üniversiteler olmak üzere kamu kurum ve kuruluşlarıyla işbirliği içerisinde hareket etmelidir. Ayrıca yerel yönetim birimleri içerisinde 1 şık kirliliği konusunda uluslararası kuruluşların yapmış olduğu çalışmaları inceleyecek birimin oluşturulması bu yolla güncel gelişmelerin takip edilmesi sağlanmalıdır. Bunun yanı sıra Almanya'da hükümetin böcekleri korumak adına çıkarmış olduğu yasa ile 1şık kirliliğine ve pestisit kullanımına yeni kurallar getirmesi ve doğal koruma alanlarını genişletmesi bu anlamda önemli bir adımdır (Ekoiq, 2021). Günümüzde birçok ülke 1şık kirliliğini sınırlandırmak adına yasal düzenlemeler yapmaktadır. Bu amaçla büyük gözlemevlerinin bulunduğu Kanarya Adaları ile ABD’nin Arizona, Maine ve Texas eyaletleri özel kanunlarla korunmaktadır. ABD ve Kanada, Belçika, Almanya, Fransa, İngiltere, Yeni Zelanda ve Japonya gibi ülkelerde altmıştan fazla yerel yönetimde ilgili kanun ve yönetmelikler hazırlanmaktadır. Temmuz 1999'da Viiyana'da düzenlenen Conference on the Use of Space for Peaceful Purposes (Mekanın Barışçıl Amaçlarla Kullanımı Konferansı)'nda bir karar alınmıştır. Bu karar ile Birleşmiş Milletler'e üye devletlerin hem 1şık hem de diğer nedenlerle gökyüzünün kirlenmesini kontrol etmeleri istenmektedir (Küçük ve Eken, 2021: 195). Türkiye'de de benzer çalışmaların yapılması bu farkındalığın artırılması için oldukça önemlidir.

$\mathrm{Bu}$ çalışma farkındalık oluşturarak bireylere ve kurumlara ışık kirliliği konusunda sorumluluk almasının gerekliliğini belirtmektedir. Bireysel anlamda yaşadığımız ortamlarda konuya dikkat ederek gereksiz ışık kullanımından kaçınmak kurumsal anlamda da gerekli yönetmelik ve kanunları özümsemek ve buna yönelik çalışmalar yapmak ve halkı bilgilendirmek 1şık kirliliğini önlemeye katkı sağlayacaktır.

\section{KAYNAKÇA}

Ankara Üniversitesi. (2020). Ankara Üniversitesi Açık Ders Notları. (H. Perçin, Dü.) 0612,2021 tarihinde https://acikders.ankara.edu.tr/pluginfile.php/61578/mod_resource/content/1/16.\%20B\%C3\%B61\%C3\%BCm\%20D\%C4\% B1\%C5\%9F\%20mekan $\% 20$ ayd $\%$ C4\%B1 nlatmas $\%$ C4\%B1.pdf adresinden alınd 1

Bennie, J., Davies, T., Cruse, D., Inger, R., \& Gaston, K. (2015). Cascading Effects Of Artificial Light At Night: ResourceMediated Control Of Herbivores İn A Grassland Ecosystem. The Royal Society, 1-9.

Bostanc1, B. (2016). Dijital Göz Yorgunluğu Sendromu ve Kuru Göz. MN Oftalmoloji Kuru Göz Özel Saylsl, 23 , 96-99.

Chepesiuk, R. (2009). Missing The Dark: Health Effects Of Light Pollution. Environmental Health Perspectives, $117(1), 20-27$.

Çimen, A. Akbaş, Y. \& Erbaş, O. (2018). Uyku, Melatonin ve Kanser İlişsisi. FNG \& Demiroğlu Bilim Tıp Transplantasyon Dergisi, 3(2), 38-41.

Ercan, E. (2018). Harcama ve Öz Gelir Seviyeleri Bakımından Yerel Mali Özerklik. Maliye Dergisi, 174, $502-517$.

Ekoiq (2021). Almanya'da Çevre Hareketlerinin Sesi Artık Daha da Gür. https://ekoiq.com/2021/03/24/almanyada-cevrehareketlerinin-sesi-artik-daha-da-gur/ adresinden alındı

Gaston, K. (2013). Sustainability: A Green Light For Efficiency. Nature, 560-561.

IDA. (2016, 05 10). 80\% of World Population Lives Under Skyglow, New Study Finds. https://www.darksky.org/80-of-worldpopulation-lives-under-skyglow-new-study-finds/ adresinden alındı

İDA. (2020). Işık Kirliliğinin Yaban Hayatı ve Ekosistemler Üzerindeki Etkileri. https://www.darksky.org/lightpollution/wildlife/ adresinden alındı 
İDA. (2021). Light Pollution. https://www.darksky.org/light-pollution/ adresinden alındı

İzmir Büyükşehir Belediyesi. (2021). İzmir'de Yaşam. https://www.izmir.bel.tr/tr/BuyuksehirSinirHaritasi/125/212 adresinden alınd1

Küçükalay, M. (1997). Endüstri Devriminin Sonuçları ve Analizi. Süleyman Demirel Üniversitesi İktisadi ve İdari Bilimler Fakültesi Dergisi, 51-68.

Küçük, Z., \& Ekren, N. (2021). Light Pollution and Smart Outdoor Lighting, Balkan Journal of Electrical and Computer Engineering, 9(2). 191-200.

LRC. (2000). Lighting Researcher Center. https://www.lrc.rpi.edu/resources/publications/pdf/illuminationfund.pdf: https://www.lrc.rpi.edu/resources/publications/pdf/illuminationfund.pdf adresinden alınd1

$\begin{array}{lllllll}\text { MEB. (2011). } & \text { Milli } & \text { Eğitim } & \text { Bakanlığı. } & 06 & 11, & \text { tarihinde }\end{array}$ http://www.megep.meb.gov.tr/mte_program_modul/moduller_pdf/\%C4\%B0\%C3\%A7\%20Ayd\%C4\%B1nlatma\%20Tesi satlar $\% \mathrm{C} 4 \% \mathrm{~B} 1 . p d f$ adresinden alınd 1

Meyer, $\quad$ S. $\quad$ (T.B). Light

http://academics.wellesley.edu/EnvironmentalStudies/Curriculum/ES\%20101/Light\%20Pollution\%20.pdf alındı

MW. (2021). Merriam Webster . https://www.merriam-webster.com/dictionary/light adresinden alındı

NAOJ. (2016). Light Pollution. https://www.iau.org/static/archives/images/pdf/light-pollution-brochure.pdf adresinden alınd1

OXFORD. (2021). Oxford Learners Dictionaries. https://www.oxfordlearnersdictionaries.com/definition/english/light_1?q=light adresinden alındı

Özkaya, M. (2004). Aydınlatma Tekniği. İstanbul: Birsen Yayınevi.

Özkaya, M., \& Tüfekçi, T. (2011). Aydınlatma Tekniği. İstanbul: Birsen Yayınevi.

Rajkhowa, R. (2012). Light Pollution and Impact of Light Pollution. International Journal of Science and Research, 861-867.

Rea, M. (2002). Light Much More Than Vision. Proceedings of Light And Human Health, 1-15.

Sharıff, N. N. \& Osman, M. R., \& Faid, M. S. (2016). 'Creating Awareness on Light Pollution' (CALP) Project: Essential Requirement for School-University Collaboration. International Conference on Industrial Engineering, Management Science and Application (s. 1-4). Jeju: IEEE.

Smolensky, M. (2013). Book Review: Light Pollution as a New Risk Factor for Human Breast and Prostate Cancers. Chronobiology International, 30(9), 1203-1204.

SPİE. (2015). International Society for Optics and Photonics. https://spie.org/Documents/resources/Free\%20Posters/LightPoster.pdf adresinden alınd 1

Şirel, Ş. (1991). 07 04, 2021 tarihinde http://sazisirel.com/booklets/sistemdekor.pdf adresinden alındı

Şirel, Ş. (2007). Aydınlatma Semineri Notları. https://sazisirel.com/booklets/AydSemDersNotu.pdf adresinden alındı

TBMM. (2005). Belediye Капипи. https://www.mevzuat.gov.tr/MevzuatMetin/1.5.5393.pdf adresinden alınd1

Topal, T. \& Öter, Ş., \& Korkmaz, A. (2009). Melatonin ve Kanserle İlişkisi. Genel Tıp Dergisi, 19(3), 137-143.

Turgay, O. \& Altuncu, D. (2011). İç Mekanda Kullanılan Yapay Aydınlatmanın Kullanıcı Açısından Etkileri. Çankaya Üniversitesi Bilim ve Mühendislik Dergisi, 8(1), 167-181.

Ultan, M. Ö. (2018). Dünyadaki Nüfus Artışı Konusuna Avrupa Birliği ve Birleşmiş Milletler Yaklaşımları. Sosyal Bilimler Dergisi, 82-92.

UN. (2020). Decisions Of The Conference Of The Parties To Cms In Effect After Its 13th Meeting. https://www.cms.int/sites/default/files/document/cms_cop13_decisions_e_rev.1.pdf adresinden alındı

Yontar, İ. G. \& Özer, Y. E. (2018). Yerel Demokrasinin Kalite Göstergesi Olarak İdari ve Mali Özerklik. Hukuk ve İktisat Araştırmaları Dergisi, 10(2), 99-110. 